HAMLIN GARLAND 


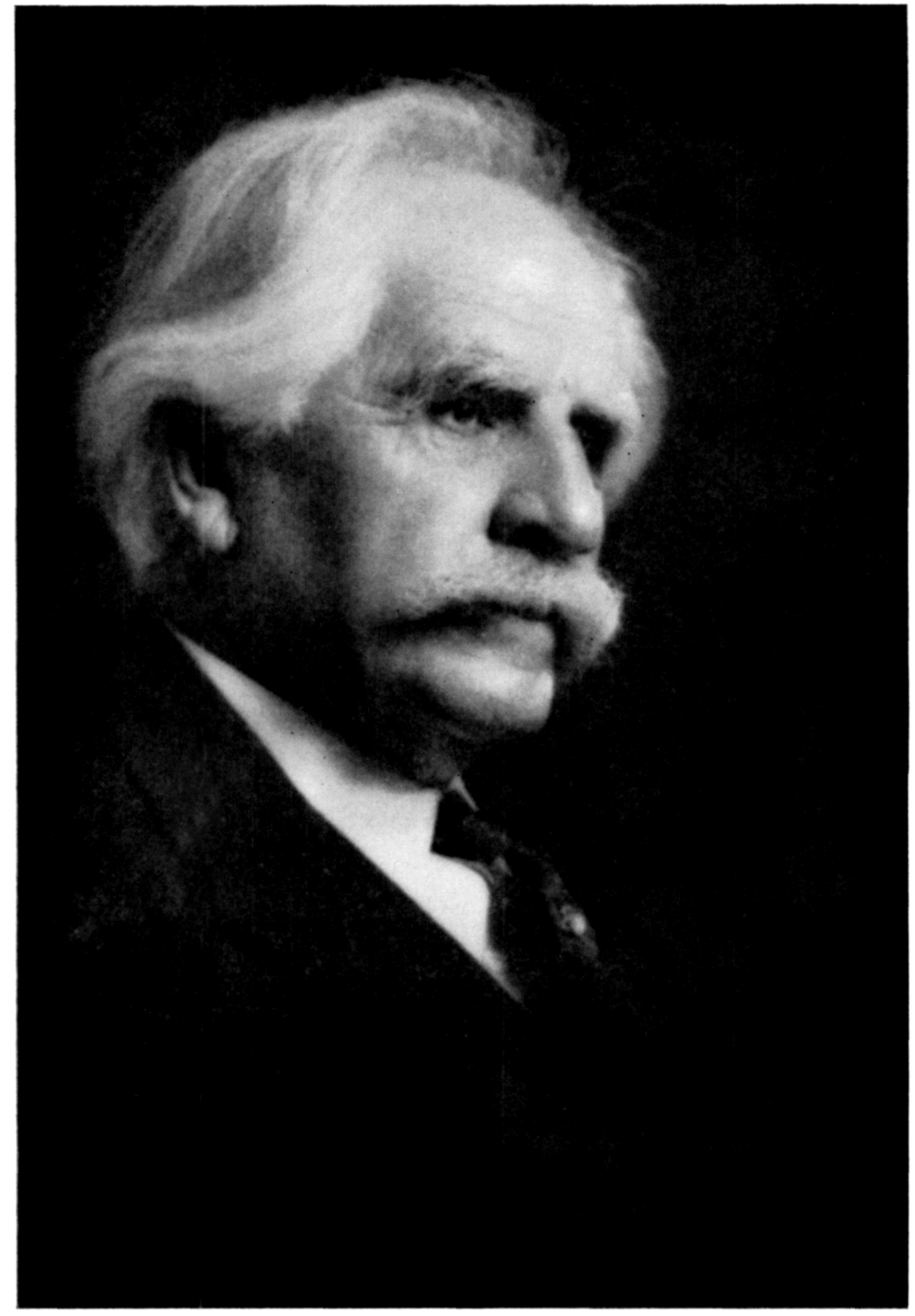




\title{
Hamlin Garland
} 类 A B I O GRA P HY 苟

\author{
By Jean Holloway
}

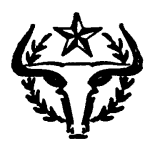

U NIVERSITY OF TEXAS PRESS - A USTIN 
Copyright () I960 by Jean Holloway

First paperback printing 2014

All rights reserved

Requests for permission to reproduce material from this work should be sent to:

Permissions

University of Texas Press

P.O. Box 78 I9

Austin, TX 787 I3-78I9

http://utpress.utexas.edu/index.php/rp-form

Library of Congress Catalog Number 59-8 I 24

ISBN 978-I-4773-07I4-4, paperback

ISBN 978-I-4773-07 I 5-I, library e-book

ISBN 978-I-4773-07I6-8, individual e-book 
To Joan 
THIS PAGE INTENTIONALLY LEFT BLANK 